\title{
Russia and the West: Are Values the Problem?
}

Ivan N. Timofeev

\author{
Ivan N. Timofeev, PhD in Political Science \\ MGIMO University of International Affairs, Moscow, Russia \\ Associate Professor; \\ Russian International Affairs Council, Moscow, Russia \\ Program Director
}

ORCID: 0000-0003-1676-2221

Scopus Author ID: 35293701300

SPIN-RSCI: $3517-3084$

Tel: +7(495)434-67-66

E-mail: itimofeev@russiancouncil.ru

Address: Office 324, 76 Vernadsky Prospect, Moscow 119454, Russia.

This is an edited version of the paper originally written for the Valdai Discussion Club: https://valdaiclub.com/a/highlights/russia-and-the-west-are-values-the-problem/

DOI: $10.31278 / 1810-6374-2021-19-3-156-163$

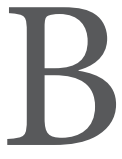
y declaring that the West is a force that promotes "broad views of life," we can find, to put it mildly, misunderstandings among large segments of the population in Western countries who hold completely opposite views. Any generalization here requires careful calculation and elaboration.

The National Security Strategy of the Russian Federation approved by the President of Russia will go down in history as a document that sharpened the issue of the country's traditional spiritual and moral values. Values were also featured in the predecessor Strategy 2015. However, Strategy 2021 has new accents. The source of the threat is the "Westernization" of culture. Russian values, according to the document, are being attacked by the United States and its allies, 
transnational corporations, as well as foreign non-profit, nongovernmental, religious, extremist, and terrorist organizations. If earlier terrorism and extremism, in one way or another, were separated from the "Western" theme, now they are considered threats of the same order. The transition of confrontation with the West into the realm of values is a new stage in Russian strategic thinking. Earlier such confrontation was perceived more in terms of material categories (defense, economics), but now it has clearly shifted to an ideological level. Why did this transition take place? What problems will Russia face in the new paradigm, and what are the strengths and weaknesses of this approach?

Let us start with the premises. Russian foreign policy has been deviating from the value dimension for quite a long time. A certain surge occurred in the early 1990s with the idea that Russia's values were converging with those of the West. But by the second half of the 1990s, there was a clear departure from liberal idealism towards pragmatic realism. In the early 2000s, realism finally took root in Russian doctrines. We viewed security and foreign policy in terms of specific material threats. It is on this basis that interaction with external forces, including the West, was built. The realism of Russian thinking was determined, on the one hand, by fatigue from the excessive ideologization of Soviet foreign policy, and, on the other hand, by quick disappointment in political rapprochement with the West and the understanding that declarations of common values do not necessarily mean avoiding competition.

Western foreign policy, on the other hand, retained its ideological burden. Russia quickly returned to the ranks of the "significant others." That is, it again became a reference point against which the Western identity was built. New residents of the "Western House" from the countries of Central and Eastern Europe played a role here. For them, the formation of a new identity was a particularly important task and opposing the former "empire" was a convenient political technology. This process began long before the events in Crimea in 2014. Voices about Russian authoritarianism, expansionism, etc. began to be heard back in the early 2000s, paradoxically, simultaneously with statements 
about the inevitable extinction of the once mighty power. Identity games have also become a political technology in the post-Soviet space. The notorious "color revolutions" unfolded, among other things, on the basis of the opposition's concept of "modern West vs. backward Russia."

In Russia itself, positioning the West as a "significant other" was initially the lot of the opposition. In the 1990s, both the left and the right built their election campaigns on it. The former exploited nostalgia for Soviet times, the latter exploited the demand for "geopolitical" revenge. In the 2000s, such a narrative partly moved to the level of state policy, although it did not reach the level of open opposition between value models. The process accelerated after 2014, but even then, the value component of the Russian approach to the West was noticeably less significant in comparison with the narratives of individual Western countries and organizations. In 2021, the value load of Russian strategic thinking approached the Western one. What used to be veiled and remained between the lines is now called by its proper names. At the same time, the core values proposed by the new Strategy will face several conceptual problems.

The first problem is related to the fact that the values that are proclaimed in the Strategy-Russian spiritual and moral guidelines as opposed to "Westernization" - are either of Western origin, or, at least, are not alien to the West. Among them, the document notes life, dignity, human rights and freedoms, patriotism, citizenship, service to the nation, high moral ideals, a strong family, creative work, the priority of the spiritual over the material, humanism, mercy, collectivism, mutual assistance and mutual respect, historical memory, and the continuity of generations.

Rights and freedoms are the values of the Enlightenment, the cradle of which is Western Europe. The same goes for patriotism and citizenship. The English Revolution, the French Revolution, and then a series of other revolutions in Europe paved the way for them. The revolutions in Russia itself also took place under the same slogans, although the Russian imperial government managed to organically integrate patriotism into its system of values. Life and dignity are rather universal 
values and are certainly shared by many in North America and Europe. In the West, it is difficult to find a society that would abandon the high moral ideals and values of the family, despite several waves of "sexual revolution" and emancipation. Creative labor is at the core of Western economic ethics. It is a combination of the spiritual and the material. To regard the capitalist West as an adherent of the primacy of the material would be an exaggeration. Suffice it to recall the Protestant ethics and the "spirit of capitalism," or the high religiosity in some societies. Inglehart's large-scale studies have shown that the choice between conditionally spiritual and conditionally material priorities changes cyclically, that is, one generation can be driven by materialists, the next by idealists, and the next one by materialists again.

Humanism is a Western concept. By and large, it underlies a liberal political theory with its assumption of the creative nature of man and human life as the highest value. Mercy, mutual assistance and mutual respect are universal values. The same goes for justice. Moreover, it is in Western political thought that the theory of justice has been the subject of reflection for centuries and even millennia from Plato's just state to John Rawls' theory of justice. Finally, collectivism is also present in the Western value matrix, which includes both ideas of the common good and theories of the political community. Within the West itself, there are societies that are more "collectivist," or conversely, more "individualistic."

The second problem is related to the fact that the West itself is extremely heterogeneous. It consists of many ways and cultures. Yes, there is a common narrative promoted by security organizations (NATO), those promoting economic and political integration (the EU), and individual nation states. But under this surface there is a great degree of variety, which simply cannot be brought down to a common denominator. Conservative Poland, with its restrained attitude towards migrants, high religiosity and the prohibition of abortions, coexists with a multicultural Germany, which has much wider boundaries of tolerance. Within Italy, there are at least two subcultures: one of the North and the other one of the South. Moreover, they differ radically in the organization 
of society, in labor ethics, and in electoral preferences. The United States is also distinguished by its significant level of diversity, even though it is often mistakenly regarded as a kind of homogeneous organism, transmitting values of the same order abroad. Internal differences are sometimes colossal. What are the informal rifts between the North and the South that have been preserved since the Civil War? In America, we will also find polarized views on the point of sexual minorities, which Russian critics love to debate. Views of tolerant California will be very different, for example, from those of "the Cotton Belt." The occasional murder of members of sexual minorities is a part of American life. They can happen anywhere. We can recall the historical experience. The well-known McCarthyism of the 1950s coexisted with the activities of John Peurifoy, the Deputy Undersecretary of State for Administration. He "exposed" the "homosexual underground" in his department, firing 91 employees. True, at that time, representatives of minorities were also considered to be clandestine communists.

In short, by declaring that the West is a force that promotes "broad views of life," we can find, to put it mildly, misunderstandings among large segments of the population in Western countries who hold completely opposite views. Any generalization here requires careful calculation and elaboration.

Finally, the third problematic aspect is the specificity of the Russian society itself. Since at least the 17 th century, we have been under the powerful cultural and civilizational influence of the West. Moreover, the openness to such influence was a deliberate decision of the political elites. The Westernization of Russia began at the top and was actively promoted by the Russian leaders with certain fluctuations for more than three centuries. We tried to borrow the core of the Western experience-the rationalization of key political institutions and their transformation into a smoothly working efficient machine, meaning primarily the army, bureaucracy and instruments of disciplinary power. Without this borrowing, Russia, apparently, would have suffered the same fate as China in the 19th century, which was literally torn to pieces by more advanced opponents. Instead, the modernization 
of the army and the political apparatus in accordance with Western models brought Russia the status of a great power.

Throughout the 19th century, battles between Westernizers and Slavophiles were fought in Russia. Both camps were not satisfied with the half-heartedness of modernization and relations with the West. The Slavophiles called for "returning to the roots," believing that borrowing only distorted and disfigured the Russian historical path. The Westernizers, on the contrary, called for completing the process, not to be limited to the army and the system of coercion, and modernizing all social and political institutions.

The revolution of 1917 and the victory of Soviet power can hardly be considered a victory for the Westernizers or Slavophiles. But the form of Westernization which is familiar to us was preserved and even enhanced. Socialist (communist) ideology itself was of Western origin. Yes, the Russian Marxists made their notable and original contributions to it. But the basic principles remained those of the Enlightenment and rationalism, that is, Western: the belief in the creativity of man (anthropological optimism and humanism), and emancipation in all spheres, including, incidentally, the family and sexual relations, and the primacy of human rights and freedoms. Needless to say, it all turned out a little differently. In fact, the usual imperial model of modernization was reproduced: the development of the army, the apparatus of disciplinary power, as well as all the industrial and scientific potential necessary for a modernization breakthrough. At the same time, the space of non-freedom was preserved and strengthened significantly. The mixture of modernization of institutions of coercion with the mass character of modernization according to the Western model, among other things, gave rise to specific forms of totalitarianism being set up within society, which, however, became softer over time. The eternal half-heartedness of our Westernization, its exaggeration in some areas, and sublimation in others, became one of the reasons for the collapse of the Soviet state.

Is the dispute between conventional Westernizers and Slavophiles relevant now? Unlikely so. In the 19th century, Russia really did have a cultural base of the bearers of "traditional" values. These were villages 
and large masses of people who were not involved in modern forms of organization of the economy and society. The deepest rupture and at the same time the inextricable connection between them and the elite of the time is perfectly described in classical Russian literature. However, in the 20th century, this base was largely destroyed. The Soviet modernization project melted agrarian Russia into an industrial and urbanized country with a completely different way of life. Religious institutions were simply trampled underfoot. In terms of secularization, we are far ahead of the West.

In terms of urbanization and lifestyle, late Soviet and post-Soviet Russia were and are a Western society with all its attendant problems. Society has lost its traditional landmarks.

Our family institution is a typical Western model with a small number of children and a high divorce rate. Moreover, this trend was entrenched back in the 1960s. The collapse of the USSR and the economy only exacerbated all the typical problems of an urban and modernized society. There is a high level of murders and suicides, alcoholism, and the atomization of society.

In other words, it is difficult for us to offer the world and ourselves an alternative to "traditional culture," since its social base was lost during the 20th century as a result of unprecedented modernization. This made it possible to achieve monumental results and turn the Soviet Union into a superpower. But it also had a price. In comparison with Russia, the countries of, for example, the Middle East have had much more significant potential for constructing a "traditional" identity, if only because of the decisive role of religion in political public life. Is all of Russia ready for such an experience? Obviously not, especially given the fact that our country itself is rather heterogeneous. This heterogeneity increased in the post-Soviet period. The rapid modernization of large cities was accompanied by equally tangible de-modernization in some regions and segments of Russian society. Moreover, the experience of modernization and de-modernization is intricately intertwined.

Does this mean that tradition in such a society is generally impossible? Of course not. But this is a different type of tradition. 
A tradition based on patriotism, citizenship and the preservation of historical memory is not much different in structure from similar patterns adopted in many Western countries. This means that the opposition to the West here will also be quite relative.

Whether we like it or not, our ties with the West are not going anywhere. Political contradictions and a military threat will force us, at least, to take into account the Western experience of organizing the army, industry, and science.

Value impulses from various Western countries will come to us even if we strictly censor information and the public space. In Russian society, social groups persist with a demand for the modernization of the economy, institutions and society, including by using the Western model. The fact that such groups are a minority is unlikely to be directly correlated with their influence. The Russian elite itself is Westernized. There are also numerous cadres in the economy, science and other critical areas that cannot exist in a closed society. Cleansing these spheres and even mass repressions will not solve the problem in principle, because these spheres themselves work or should work within the framework of a modern and modernized society.

Finally, and most importantly, values alone do not prevent political conflicts. The peoples of Russia and Ukraine, for example, are close in terms of their respective values. But politically Moscow and Kiev are opponents. There are a lot of similar examples. The modern West is literally built on bones. For several centuries, wars between members of the "united Christian community" were an almost daily routine in international relations. The long-lasting peace of the last seventy-six years is historically an anomalous exception. One should not be afraid of values as such, but of political conflicts that can exploit these values. Russia needs modernization, which, in turn, is impossible without interaction with Western societies. Just like three hundred years ago, borrowing foreign experience and combining it with one's own vision and strategic objectives can become the key to the country's survival. 